\title{
ARILARIN YAVRU ÇÜRÜKLÜĞÜ İNFEKSIYONLARINDA DOĞRU TEŞHIS, MÜCADELE VE KORUNMA YÖNTEMLERI
}

\author{
Diagnosis of Infection, Fighting and Protection Methods in Foulbrood Infection of \\ Honeybees
}

(Extended abstract in English can be found at the end of the article)

Ebru BORUM*

Balıkesir Üniversitesi Veteriner Fakültesi Mikrobiyoloji Anabilim Dalı, Balıkesir, ebruborum@balikesir.edu.tr Geliş Tarihi: 11.03.2013; Kabul Tarihi: 21.04.2013

\section{Öz}

Türkiye; coğrafi yapısı, zengin bitki florası, nektar kaynakları, uygun ekolojisi, koloni varlığı ve arı popülasyonlarındaki genetik varyasyon bakımından bal üretimi için çok uygun olup, arıcılık açısından büyük bir potansiyele sahiptir. Ancak bütün bu avantajlara rağmen bal üretimimiz ve ihracatımız istenilen seviyede değildir. Teknik bilgi yetersizliği, bakım ve besleme noksanlığı, ana arı üretimi yetersizliği, kışlatmadaki bilgisizlik, hastalık ve zararlılarının bilinmemesi, zamanında teşhis ve tedavinin yapılamaması, gerekli mücadele ve korunma yöntemlerinin uygulanamaması gibi durumlar arıcılığa önemli zararlar vermektedir. Ülkemiz arılarında görülen bakteriyel hastalıkları, ergin arı hastalıkları ve yavru arı hastalıkları olarak iki gruba ayırabiliriz. Ancak bazı etkenler hem ergin, hem de yavru arılarda hastalık yaparlar. Ayrıca bazı etkenler petek veya kovanda yerleşerek zarar meydana getirmektedir. Bakteriler tarafından meydana getirilen yavru çürüklükleri özellikle genç larvaları etkiler. Amerikan ve Avrupa Yavru Çürüklüğü etkenleri arıcılıkta önemli kayıplara yol açmakta, ekonomiye ve arıcılığa büyük zarar vermektedir. Bulaşma; arıcılar ve arıcılar tarafından kullanılan alet ve ekipmanlar, hastalıklı kovanlar, sporla bulaşık ballarla beslenme, temel petekler, temel petekte oğul ve kolonilerin birleştirilmesi, sporları taşıyan ergin arılar, yağmacılık, sağlam arıların hastalıklı bölgeye girmeleri, bulaşık ve eski kovanların yetersiz sterilizasyon ile tekrar kullanımı, kontamine bal ve polenlerin arı gıdası olarak kullanımı ile olur. Arılıklar arasında arı ürünlerinin, ergin arılar ve kraliçe arının, kullanılmış kovanların ve arıcılık ekipmanlarının hareketlerinin kontrol altına alınması yavru çürüklüğü hastalıklarının bulaşmasında oldukça önemlidir. Bu hastalıklardan korunma tedaviden daha önemlidir. Özellikle sadece basit birkaç hijyenik kurala dikkat edilmesi bu hastalıklardan korunmada çok daha yararlı olacaktır. Bu makalede arıcılıkta sıklıkla karşılaşılan yavru çürüklüğü hastalıkları, güvenilir teşhis, korunma ve mücadele yöntemleri hakkında bilgi verilmiştir.

Anahtar Kelime: Arı, Hijyen, Yavru Çürüklüğü.

\section{ABSTRACT}

Turkey has a great potential for beekeeping. Geographical structure, rich flora, nectar sources, ecology, colony, and genetic variation in the populations of bees for honey production terms are very affordable for beekeping in Turkey. However, despite all these advantages, our honey production and exports are not good. Lack of technical knowledge, care and nutritional deficiency, queen bee production failure, wintering ignorance, disease and pests are not known, and consequently timely diagnosis and treatment can not be made, the necessary control and prevention methods are not applied to the situations.Diseases can be divided into two groups. Adult bees diseases and foulbrood diseases. American and European foulbrood factors leads to significant losses in beekeeping, beekeeping economy and great harm. Beekeepers used appliances and equipment, diseased hives, contaminated honey with nutrition, robbing, old hive inadequate sterilization again with the use of contaminated bee honey and pollen by the use as food becomes. Among the purity of bee products, 


\section{DERLEME MAKALESI / REVIEW ARTICLE}

adult bees and queen bees, hives and beekeeping equipment used to control the movements of the foulbrood is quite important in the transmission of diseases.Prevention of these diseases is more important than treatment. In particular, to pay attention to just a few simple rules of hygiene in the prevention of these diseases will be much more useful. In this article frequently encountered in beekeeping foulbrood diseases, reliable diagnosis, prevention and control methods is given about.

Key words: Honeybee, Hygiene, Foulbrood

GíRiş:

Türkiye 6 milyon koloni varlığı ile dünyada ikinci, 75 bin ton bal üretimi ile de 4 . sırada yer almaktadır. Bu balın ancak 8-10 bin tonu ihraç edilebilmektedir. Bunun \%90'ını çam balı oluşturmaktadır. Dünyada koloni başına bal verimi 20 kilo, Türkiye'de ise 16 kilodur. Türkiye, kovan başına düşen bal üretimi ile diğer dünya ülkeleri arasında son sıralarda yer almaktadır (Karacaoğlu, 2012; Konak, 2012).

Bal yanında; propolis, arı sütü, polen ve balmumu gibi arı ürünleri de dünya ticaretinde yer almaktadır. Diğer yandan tarımı gelişmiş ülkelerde arıcılık, arı ürünleri üretimi yanında hatta daha önemli olarak, bitkisel üretimde miktar ve kalitenin artırılması amacıyla yapılmaktadır. Örneğin, ABD'de bitkisel üretimde bulunan üreticiler üretim yaptıkları bitkilerde tozlaşmanın sağlanması için arıcılara 41 milyon dolar arı kirası öderlerken, buna karşılık kendileri arıların üretimlerine katkısından 3.2 milyar dolar kazanmaktadırlar. ABD'de yapılan bir çalışmada; 40 dolayındaki bitki türünden elde edilen toplam 30 milyar dolarlık ürün değerinin yaklaşık 1/3'ü olan 10 milyar doların bal arılarından sağlandığı belirlenmiştir.

Aynı zamanda bal, propolis, arı zehiri, arı sütü gibi arı ürünleri pek çok ülkede "Arı Ürünleri ile Tedavi" anlamına gelen "Apiterapi"de kullanılmaktadır. Bununla birlikte arıcılık, doğa ve çevreye zarar vermeden yapılabilen ender faaliyetlerden birisidir. Bu yönüyle de arıcılık geleceğin en önemli sürdürülebilir tarım faaliyetlerinden birisi olacaktır. $\mathrm{Bu}$ nedenle arıcılık, tüm dünyada vazgeçilemez tarımsal bir faaliyet olarak sürdürülmektedir (Kaftanoğlu ve ark., 1995; Doğaroğlu, 2000; Tutkun, 2000; Tutkun ve Boşgelmez, 2003).

Ülkemiz ballı bitkilerin çeşitliliği, dört mevsim arıcılık yapmaya uygun iklim koşulları ve bitki örtüsü yönünden hayli zengin olmasına rağmen, bal üretiminde verim düşüktür. Bunun sebepleri ise bilinçsizce yapılan arıcılık, arıcıların yeterince örgütlenmemeleri, bilinçsiz bakım besleme ve ilaç uygulamaları yapılması, ilaç uygulamaları sonucu kalıntı problemleri, arı hastalık ve zararlılarının yeterince tanınmaması, zamanında teşhis ve tedavinin yapılamaması, mücadele ve korunma yöntemlerinin bilinmemesidir.

Bakteriler tarafından meydana getirilen arı hastalıkları, özellikle de genç larvaları etkileyenler, önemli yer tutar. Bakteriyel hastalıklar içinde özellikle Amerikan Yavru Çürüklüğü (AYÇ) ve Avrupa Yavru Çürüklüğü (AvYÇ) etkenleri arıcılıkta önemli kayıplara yol açmakta, ekonomiye ve arıcılığa büyük zarar vermektedir (Bailey ve Ball, 1991; Kaftanoğlu ve ark., 1995; Tutkun ve Boşgelmez, 2003).

Hastalıklar sonucu arı kayıpları genellikle ilkbahar aylarında görülür. İlkbahar aylarında özellikle yavru yetiştirme faaliyetinin büyük hız kazanmış olması ve beklenmeyen soğuk ve yağışı havalar bu kayıpların artma sebebidir. Bu nedenle bu kritik dönemde arıların özellikle yavru hastalıklarına karşı korunması için gerekli özen gösterilmelidir

Üretim sürecinde, arıcı üretim yaparken çevresindeki arıcılara zarar verecek uygulamalardan kaçınmalıdır. Bir arıcı hastalık ve zararlılara ne kadar dikkat ederse etsin, çevresindeki arıcılar dikkat etmiyorsa önemli sorunlar yaşayacaktır.

Sınırlardan veya ithalat yoluyla bulaşık arı ve ürünlerinin ülkeye girmesi, gezginci arıcılık, koloniden koloniye arı geçişleri, arıcıların dikkatsiz davranması gibi birçok sebeple arı hastalık ve zararlıları çok hızı bir şekilde yayılmaktadır.

Pek çok patojen, arıların gerek gelişme gerekse erişkin dönemlerinde hastalık oluşturabilir. Ancak bu patojenlerin hepsi aynı derecede tehlikeli değildir. AYÇ ve Varroa gibi çok tehlikeli ve hızlı yayılan bazı arı hastalık ve zararlılarının kontrolünde "Ulusal Kontrol Programları"na intiyaç duyulur.

\section{AMERIKAN YAVRU ÇÜRÜKLÜĞÜ (AYÇ)}

Dünyanın her yerinde görülen AYÇ oldukça bulaşıCı bir hastalık olup, diğer yavru arı hastalıkları içinde en tehlikelilerindendir. Hastalığa yakalanmış kovan her geçen gün zayıflayarak söner (Morse ve Nowogrodzki, 1990; Bailey ve Ball, 1991;Kaftanoğlu 


\section{DERLEME MAKALESI / REVIEW ARTICLE}

ve ark., 1995; Shimanuki ve Knox, 2000; Tutkun ve Boşgelmez, 2003).

Bu hastalık yüksek derecede bulaşıcı bir hastalıktır ve en zararlı arı hastalıklarından biridir. Hastalık sadece bireysel olarak larvalar için değil aynı zamanda tüm koloni için oldukça öldürücü ve tehlikelidir (Genersch, 2010).Arıların çok az hastalığı AYÇ gibi bulaşıcı ve öldürücüdür. Mevsimsel olarak sık görüldüğü bir dönem yoktur. Yumurtanın mevcut olduğu her dönemde karşılaşılabilir. Ancak yumurtlamanın yoğun olduğu dönemde daha fazla görülür (İnal ve Güçlü, 1998; Tutkun ve Boşgelmez, 2003; Genersch 2010).

Hastalık etkeni Paenibacillus larvae ssp. larvae (White)'dir. Gram pozitif ve sporlu bir bakteridir. Etkenin sporları patojendir. Spor formu oldukça dayanıklıdır. Toprakta 60 yıl, kovanda 33 yıl, 100 C'ye ısıtılmış balda 30 dakika, normal balda 1$10 \mathrm{yll}$, temel petekte $45 \mathrm{yll}$, eritilmiş balmumunda 5 gün $\left(72{ }^{\circ} \mathrm{C}\right), 116{ }^{\circ} \mathrm{C}$ 'ye ısıtılımış balmumunda 20 dakika yaşayabilir. Sporlar Isıtma, soğutma ve kimyasallara oldukça dirençlidir, hem bal hem de poleni kontamine ederler (Alippi, 1999; Shimanuki ve Knox, 2000; Genersch, 2010).

Hastalık özellikle larvaları etkiler. Kolonideki işçi arı, ana arı ve erkek arı larvaları bu hastalığa yakalanabilir. Ergin arılarda infeksiyon görülmez. Ergin arılar beslenme sırasında etkeni yavrulara bulaştırabilirler. Özellikle yumurtlamadan 12-36 saat sonra en duyarlı oldukları zamandır. 10 adet spor bir larvayı infekte edebilir. Herbir larvada 2.5 milyar spor bulunabilir (Alippi, 1999; Shimanuki ve Knox, 2000; Tutkun ve Boşgelmez, 2003; Genersch, 2010). Ölü larvanın bulunduğu hücre gözünün temizlenmesi ve larvaların beslenmesi sırasında erişkin arılar tarafından hastalık kovana yayılır. Koloniler arasındaki bulaşma yolları ise farklılık gösterir. Hastalık bulunan kovandan larva ya da yumurta bulunan peteklerin, arıların sağlıklı kovanlara verilmesi, kovan birleştirme, hastalıklı kolonilerdeki polen ya da balın sağlıklı kolonilerin beslenmesinde kullanılması, yağmacılık, kovanları şaşıran arılar, hastalıklı kovanlardan elde edilen oğullar, hastalıklı kovanlardan ana arının sağlıklı kovanlara verilmesi, bulaşık kovan ve ekipmanların kullanılması, kovanların farklı bölgelere taşınması hastalığın arııktaki koloniler ve arılıklar arasında yayılmasında oldukça etkilidir (Morse ve Nowogrodzki, 1990; Alippi, 1999; Tutkun ve Boşgelmez, 2003; Genersch, 2010). Petek güvesi ve küçük kovan böceği de bulaşmada etkili olabilmektedir (Rlitter,1996; Schäfer ve ark., 2010).

Hastalık öncelikle yavruları etkiler. Genç ve erişkin arı sayısı azalmaya başlar. Kolonide yavru üretmek mümkün olmaz. Koloni zayıflamaya başlar, anormal arı uçuşları ve arılarda tembellik görülür. Kovan çevresinde kapalı ve açık gözlerden sökülerek atılış koyu renkli larvalar dikkati çeker. Peteklerdeki yavru gözleri düzensiz olup açık ve kapalı gözlerin bir arada olması nedeniyle petek alacalı ya da bulmaca manzarası denen bir görünümdedir. Ölü larvalar tam olarak petek gözlerinden uzaklaştırılamadığı için gözlerin temizlenememesi sonucu ana arı mozaik şeklinde düzensiz yumurta bırakır (Şekil 1). Bazen yavru alanlarındaki petek gözlerinde bal ve polen depolandığı görülebilir. Kapalı yavru gözlerinde kapak rengi solmuş, içeri çökmüş ve nemli görünümdedir. Ölümler genellikle kapalı gözlerde olur. Kapalı gözlerin kapakları toplu iğne başı büyüklüğünde delinmiş bir görünümdedir (Şekil 2). Ölü larvanın rengi önce donuk beyaz, daha sonra sarı, açık kahve, çikolata kahve ve son olarak siyah renge dönüşür, yapışkan bir görünüm alır. Ölü larva çikolata rengini aldığında bir kibrit çöpü sokulup çekilirse, larva iplik gibi $2.5-10 \mathrm{~cm}$ uzar (Şekil 3) (Alippi, 1999; Shimanuki ve Knox, 2000; De+ Graaf ve ark, 2006; Genersch, 2010).

Hastalık ilerlediğinde larvalar yavru gözlerine yapışır ve ergin arılar tarafından uzaklaştırılamaz, bazen zamanla kurur ve çerçeve sallandığında petek gözlerine çarparak ses çıkarabilir. Eğer ölüm pupa döneminde olursa, pupa ya da öküz dili olarak isimlendirilen ve pupaların dilinin dışarı uzaması ve petek gözünün tavanına yapışması görülür. $\mathrm{Bu}$ görünüm hastalık için tipiktir, ancak bu belirti çok yaygın olarak görülmez (Şekil 4).

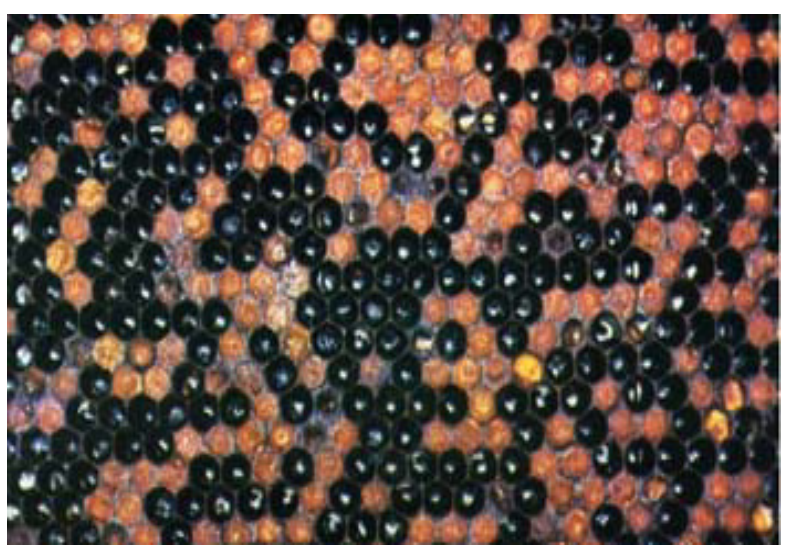

Şekil 1. http://www.beeman.ca/id6.html 


\section{DERLEME MAKALESI / REVIEW ARTICLE}

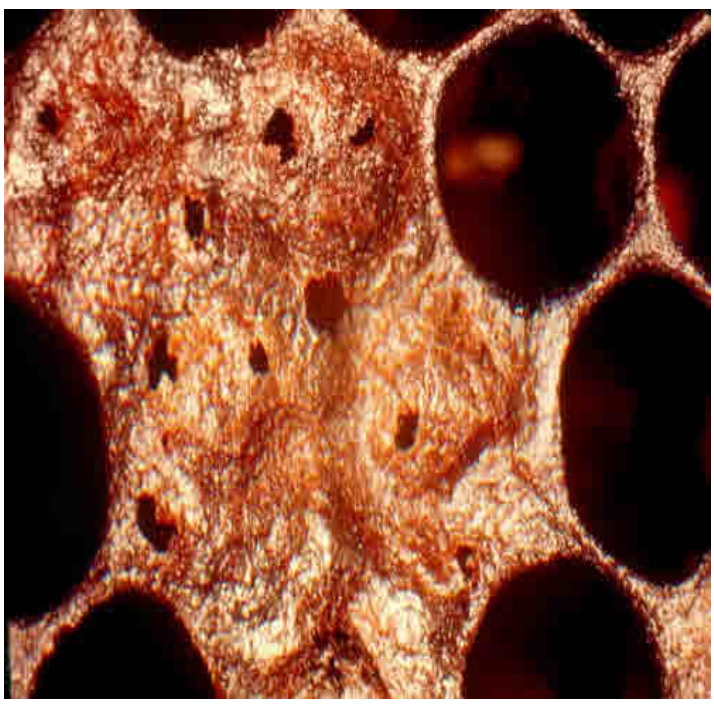

Şekil 2. www.barnstablebeekeepers.org

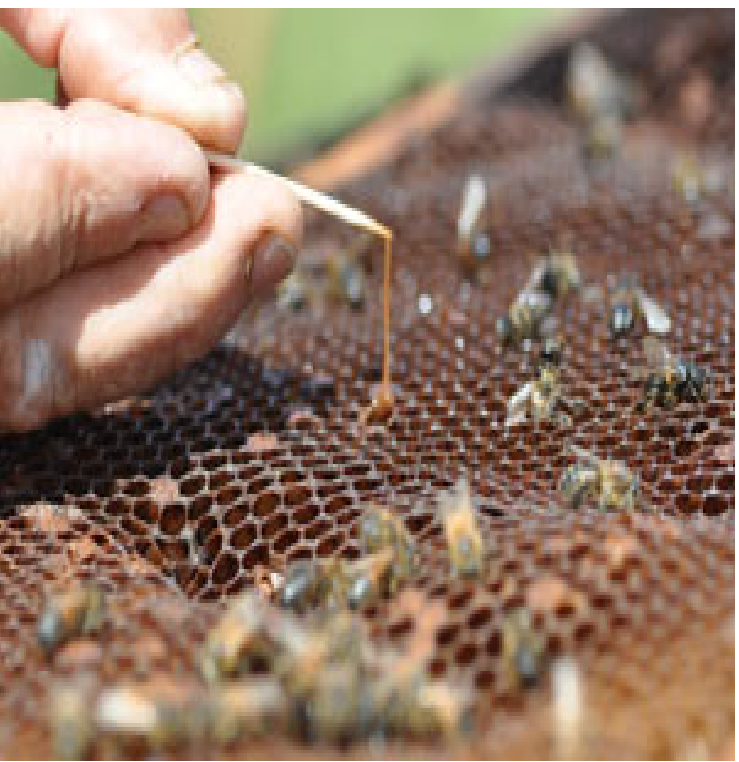

Şekil 3. www.redicecreations.com

Ayrıca hastalıklı kovanlar açıldığında zamk ya da balık kokusu hissedilir. (Alippi, 1999; Shimanuki ve Knox, 2000; De Graaf ve ark, 2006; Genersch, 2010).Bütün bu bulgular AYÇ hakkında fikir verse de kesin teşhis sadece doğru ve standart laboratuvar incelemeleri ile gerçekleşir.

Amerikan yavru çürüklüğü hemen her ülkede; ihbarı mecburi hastalıklar arasında yer almaktadır. Ülkemizde bir yerde salgın bir arı hastalığının çıktığını haber alanlar 3285 Sayılı Hayvan Sağlığı ve Zabıtası Kanununun 9. ve 10. maddelerine göre illerde Bakanlık İl Müdürlüğüne, ilçelerde İlç̧e Müdürlüğüne derhal bildirmelidir.

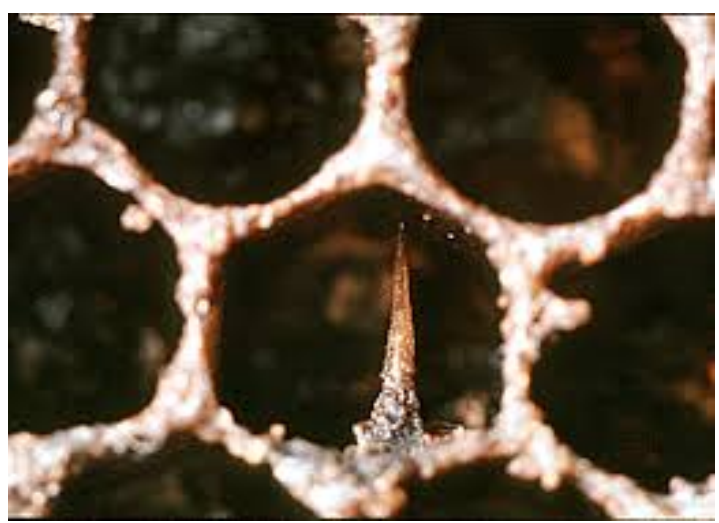

Şekil 4. http://forum.pasiekaambrozja.pl/

Arıcılıkta AYÇ'nü kontrol etmek için başarının sırrı, hastalığı erken dönemde bulmaktır. Arıcılar, kolonilerini dikkatle incelemeli, hastalığa karşı daima tetikte olmalıdır.Klinik bulgular, hastalığın teşhisinde önem taşırsa da, kesin teşhis için marazi madde alınarak laboratuvar muayenelerinin yapılması gereklidir. Arıcılar şüphelendikleri kovanlardan bal, petek ve larva örnekleri alarak ilgili teşhis laboratuvarlarına gönderebilirler.Tipik semptomlar, hastalıklı ve şüpheli örneklerden kültürel, biyokimyasal ve mikroskobik incelemeler oldukça önemlidir. Bu yöntemler genel tanı için etkili ve ekonomik olarak uygun olmakla birlikte, özellikle Amerikan ve Avrupa Yavru Çürüklüğü etkenlerinin izolasyonunda yanlış teşhise ve etkenin belirlenme süresinin uzamasına da neden olabilmektedirler.Son yıllarda özellikle birçok dünya ülkesinde daha gelişmiş ve etkili yöntemler uygulanmaya başlanmıştır. Bunlar;

Moleküler teknikler,

*PCR (Polymerase Chain Reaction) çeşitleri:

REP-PCR (Repetitive Extragenic Palindromic)

ERIC-PCR (Enterobacterial Repetitive Intergenic Consensus)

BOX elements (BOX-A1R-based Repetitive Extragenic Palindromic)

\section{*SDS-PAGE}

${ }^{*}$ Gas Chromatography (Etkenin biyokimyasal karakterini belirlemede kullanılır)

*Epidemiyolojik ve taksonomik amaçlı çeşitli DNA fingerprinting teknikleri;

RFLP (Restriction Fragment Length Polymorphism) 


\section{DERLEME MAKALESI / REVIEW ARTICLE}

\author{
ARDRA (Amplified Ribosomal DNA Restriction \\ Analysis)
}

RAPD (Random Amplified Polymorphic DNA)

AFLP (Amplified Fragment Length Polymorphism)

PGFE (Pulsed Gel Field Electrophoresis)

*Bakteriyofaj duyarlıı̆ı̆,

*Immuno teknikler,

İmmunodifuzyon testi

İmmonuflouresan testi

ELISA testi

*Üstün bakteriyel kültür teknikleri,

$\mathrm{Bu}$ amaçla kullanılan birçok özel besiyeri vardır. Paenibacillus larvae agar (PLA), MYGP agar, Thiaminli Brain Heart İnfusion agar kullanımaktadır (Bailey ve Ball, 1991; Alippi, 1999; De Graf ve ark., 2013; Forsgren ve ark., 2013).

Sonuç olarak geleneksel ve ileri tekniklerin birlikte kullanılması ile özellikle de moleküler tekniklerin uygulanması ile;daha hızlı, daha duyarlı, daha güvenilir, sonuçlar alınabileceği tüm dünya ülkelerinde kabul görmüştür (Alippi ve Aguilar, 1998; Djordjevic ve ark., 2000; Uygur ve Girişgin, 2008; Human ve ark. 2011; De Graaf ve ark. 2013; Forsgren ve ark. 2013).

Hastalığın ilerleyen vakalarda tedavisi oldukça zordur. Ancak hastalık yeni başlamış ve hemen fark edilmiş ise tedavi şansı vardır. Hastalık fark edildiğinde öncelikli amaç hastalığın yayılmasını engellemektir. Hastalık şüphesi bulunan kovanın arılıktan uzaklaştırılması gereklidir. Bu uzaklaştırma yaklaşık $5 \mathrm{~km}$. olursa çok daha iyi olur.

Dünyanın bazı ülkelerinde yasal olarak, Türkiye'de ise yasak olmasına rağmen bazı arıcılar tarafından koruma amaçı antibiyotik kullanılmaktadır. Sadece arıcılık alanındaki antibiyotikler değil hayvan ve insan sağlığında kullanılan antibiyotikler dahi arıcılıkta kullanılmaktadır. Ancak antibiyotik sadece etkenin vegetatif formuna etkilidir. Hastalığa sebep olan ise etkenin sporlarıdır. Antibiyotik uygulaması geçici olarak belirtileri baskılayabilir, ancak sonra tekrar ortaya hastalık çıkabilir. Yavru çürüklüğü için kullanılan antibiyotiklerin koruma amaçlı ve sürekli kullanılması bir taraftan ballarda kalıntı problemlerine sebep olmakta diğer taraftan ise etken antibiyotiğe karşı direnç geliştirebilmektedir. Aynı zamanda gereksiz ilaç kullanımı arılarda mantar infeksiyonlarını da tetiklemektedir. Bu sebeple başta Avrupa Birliği'ne üye ve Türkiye gibi üye adayı ülkeler başta olmak üzere birçok ülkede, bu gibi nedenlerle antibiyotiklerin tedavi ya da korunma amaçlı kullanımı yasaktır.

\section{MÜCADELE YÖNTEMLERI:}

1-Hastalıklı kovan ve balın imhası: Ülkemizde ihbarı zorunlu olan bu hastalıkla en kesin ve etkili mücadele yöntemi, hastalıklı kolonilerin tümüyle yakılarak yok edilmesidir. Kovan gövdesi pürmüzle iyice alevden geçirilerek yakılmalı ve körük, maske, el demiri, yemlik, ana arı ızgarası gibi bulaşık olan malzemeler dezenfekte edilmelidir. Böylece hastalığın diğer kolonilere bulaşması önlenmiş olur. Çerçeve ve kapaklar arı, larva, propolis, bal ve balmumundan arındırıldıktan sonra yakılmalıdır. $\mathrm{Bu}$ artıkları temizlemek için önce el ile kazıma, sonra kostik soda ile suda kaynatma ya da sadece suda kaynatma yapılabilir. Daha sonra büyük bir çukur açılarak yakılır. Bu işlemin yağmacılığı önlemek ve daha rahat çalışabilmek için gece yapılması daha uygundur. İnfekte kovanlarda arılar, bal, infekte larva ve çerçeveler yakılarak yok edilmelidir. Bu amaçla kovan arılıktan uzak bir alana götürülerek hastalığın bulunduğu kovanın girişi gece, bir gazete kağıdı ya da maskeleme bandı ile kapatılır ve kovana arıları öldürmek için insektisid dökülür. Yaklaşık 48 saat sonra da kovan yakılır. Fakat arıcı bunu yüksek maliyet ve uğradığı ekonomik zarar nedeniyle uygulamak istemez. Bunun için alternatif yöntemler geliştirilmeye çalışılmaktadır (Hansen ve Broodsgaard, 1997; Anonim 2007; Tutkun ve Boşgelmez, 2003).

2-Silkeleme: Hastalıklı kovanın arıları ve ana arısı boş ve temiz bir kovana alınır. Yeni kovana temiz temel petek konur. Yavrulu ve ballı çerçeveler kesinlikle yakılmalıdır. Hastalıklı kovandan elde edilen ballar kesinlikle ve kesinlikle arıları beslemede kullanılmamalıdır. Arıların bal midelerinde bulunan kontamine balın arılar tarafından harcanması sağlanır. Nektar akımı zayıfsa uygulamadan 1 gün sonra şurup verilir. Bundan 3-4 gün sonra kovana bulaşık olmayan kabarmış petek, ballı ve yavrulu çerçeveler verilmelidir (Hansen ve Broodsgaard, 1997; Parvanov ve ark., 2006).

3-Radyoaktif uygulama: Gamma ışını uygulamasıdır. Kobalt - 60 kaynağı tarafından yayılan gamma ışınları, P.I.larvae spor, endospor ve vegetatif formlarını öldürmüştür. Kontamine petek ve ahşap ekipmanın sterilizasyonunda güvenle kullanılır. Arı beslenmesinde kullanılan polen ve bal da bu işleme tabi tutulur. Ancak bunu 


\section{DERLEME MAKALESI / REVIEW ARTICLE}

arıcıların uygulaması pek mümkün değildir (Arbia ve Babbay, 2011; Guzmana ve ark. 2011).

4-Sıvı parafine daldırma:Hastalıklı kovanın arıları, petekleri ve balı yakıldıktan sonra ahşap kovan ve uygun alet ve ekipman 10 dakika süreyle ısıtılmış $160^{\circ} \mathrm{C}^{\prime}$ deki parafine batırılır. Ancak deri ile temas olursa ciddi yanıklar oluşabilir (Dobbelaere ve ark., 2001; Bogdanov, 2009; Arbia ve Babbay, 2011).

$\mathrm{Bu}$ son 2 yöntemin arıcılar tarafından uygulanabilirliği tartışmalıdır. Son yıllarda esansiyel yağların hastalıkla mücadelede kullanımıyla ilgili araştırmalar yapılmaktadır. Laboratuvar koşullarında yapılan incelemelerde oldukça da etkili bulunmuştur. Bu yağlar hem kovanda kalıntı bırakmamaktadır, hem de arılar için zararlı değildir. Fakat bu çalışmalar henüz daha yeni oluğu için koloni bazında başarılı olduğuna dair bilgiler henüz sınırıdır ve araştırmalar devam etmektedir (Alippi ve ark., 1996; Gende ve ark., 2008, Gende ve ark., 2009).

Metal şurupluklar, el demiri, körük, ana arı ızgarası, maske, eldiven $v b$. malzemeleri dezenfekte etmek için ise kaynar su, su ve buhar, potasyum hipoklorit, çamaşır suyu, hidrojen peroksit, zefiran,potasyum ve sodyum sabunu, kireç kaymağı, kireç, sönmemiş kireç, kostik soda, kostik potas, oksijenli su, doğal bitki özleri; sitrik, formik, laktik, oksalik ve asetik asit; alkol, formol ve sodyum karbonat kullanılabilir (Matheson ve Reid, 1992; Okayama ve ark., 1997; Dobbelaere ve ark., 2001; Bogdanov, 2009; Arbia ve Babbay, 2011).

Aynı zamanda hastalık çıkan kovanda ananın değiştirilmesi de oldukça yararlı olacaktır.

Tedaviden daha çok hastalığın oluşmasını engellemek yani korumak asıl önemli olandır.

\section{KORUNMA:}

AYÇ oldukça hızlı yayılan ve zarar gücü yüksek olan bir hastalıktır. Bu nedenle korunma tedbirlerini uygulamak oldukça önemlidir. Bunları kısaca özetlersek (Matheson ve Reid, 1992; Kaftanoğlu ve ark., 1995; Alippi, 1999; Tutkun ve Boşgelmez, 2003; Anonymus, 2007; Hutton, 2013);

1-Arıcılar hijyenik çalışmalı.

2-Hastalıklı kolonilerden bal, petek, çerçeve, ana arı, iş̧̧i arı ve yavrulu çerçeveler başka bir kovana aktarılmamalıdır.
3-Kaynağı bilinmeyen oğullar arılıklara sokulmamalı, oğul kovana alındıysa en az 3 ay süre ile arııktan uzakta tutulmalıdır.

4-Ana arıyı değiştirirken, ana arının hastalıklı koloniden olmamasına dikkat edilmelidir.

5-Koloniler kaynağı bilinmeyen bal ve polenle beslenmemelidir.

6-Illkbahar ve sonbahar dönemlerinde koloniler açılmalı ve hastalık semptomları açısından kontrol edilmelidir. Hastalığın erken dönemde belirlenmesi yayılmasına da engel olur.

7-Hastalığın ilk görüldüğü kovanlar derhal arılıktan uzaklaştırılmalı, bu kovana ait bal, petek ve yavrulu çerçeveler imha edilmelidir.

8-İnfekte koloniler ile temas eden tüm alet ve ekipman (eldiven, körük, el demiri, maske vb.) temizlenmeli ve dezenfekte edilmelidir.

9-Temiz materyal ile kontamine materyal karıştırılmamalıdır.

10-Koloniler arası yağmacılığı önleyici tedbirler alınmalıdır.

11-Arılıkta petek, bal vb. artıklar bırakılmamalı, arılık, arıcılık alet ve ekipmanları temiz tutulmalı ve alet ve ekipmanlar her çalışmadan sonra dezenfekte edilmelidir.

12-Arıcılar kovan kontrollerinden önce ve sonra ellerini sabunlu su ile yıkamalıdır.

13-Diğer arı zararlıları ile (varroa, petek güvesi vb.) mücadele edilmelidir.

14-Arlığa yakın diğer arılıklara da dikkat edilmelidir. 15-Kovanlar sık sık kontrol edilmelidir.

16-Eski petekler düzenli olarak yenilenmelidir.

AYÇ'nin kontrolünde;

*Antibiyotik kullanılmaması,

${ }^{*}$ Genetik olarak hastalığa dirençli arı ırkları ve ana arı ile çalışııması,

*Bütün arıcıların AYÇ mücadelesini iyi öğrenmesi, bu hastalığın diğer arı hastalıklarından daha tehlikeli ve farklı olduğunu bilmesi, erken teşhis için sık sık kovanları kontrol etmesi en etkili mücadele ve korunma yöntemleridir. 


\section{DERLEME MAKALESI / REVIEW ARTICLE}

\section{AVRUPA YAVRU ÇÜRÜKLÜĞÜ (AvYÇ)}

$\mathrm{Bu}$ hastalık, dünyanın birçok ülkesine yayılmış tehlikeli bir yavru hastalığıdır. Hatta bazı ülkelerde AYÇ'den daha etkilidir.Hastalığın asıl etkeni Melissococcus pluton'dur. Hastalıkta sekonder bakterilerde görülür. Fakat $M$. pluton, hastalıklarla ilgili diğer bakterilerin görülmesinden önce, hastalığın erken devresinde görülür. Sekonder bakteriler hastalığa neden olmazlar fakat ölü larvanın kıvamı ve kokusu üzerinde etkili olurlar. Sekonder bakteriyel etkenler, Paenibacillus alvei (indikatör mikroorganizma), Achromobacter euridice, Brevibacillus laterosporus Enterococcus faecalis ve Paenibacillus apiarius'dur.

Melissococcus pluton sporlu bir bakteri değildir. Avrupa Yavru Çürüklüğü (AvYÇ) AYÇ'ye göre tedavi edilmesi daha kolaydır. Etken arı bağırsağında 3 yıl, arı keki, bal ve eski peteklerde 1 yıl, balmumunda 65 gün, kaynayan suda ise 15-20 dakika, $116^{\circ} \mathrm{C}$ 'de ise 2 dakika canlı kalabilmektedir (Kamburov ve Parvanov, 1987; Genç ve Dodoloğlu, 2002; Russenova ve Parvanov, 2005; Forsgren, 2010).

Hastalığın meydana gelmesinde iklim koşulları, kış sonu bahar başlangıcında görülen nosema, hafniosis, kolibakteriozis ve mantar hastalıkları arı ailesini zayıflatarak AvYÇ'nin ortaya çıkmasına zemin hazırlar. Özellikle varroa, arının gövdesini delip hemolenfini emerek sekonder etkenlerin girmesine sebep olur (Kamburov ve Parvanov, 1987; Engels ve ark., 2004).

Hastalık genellikle ilkbahar ve yazın ilk yarısında (çoğunlukla Mayıs-Haziran aylarında) yavru yetiştirmenin yoğun olduğu nektar akımının başladığı dönemde görülür. Nektar kıtlığı ve soğuk hava koşullarında hastalık ortaya çıkar. Kovana gelen nektar miktarı en yüksek düzeye ulaştığında hastalığın şiddeti de azalır. Hastalıklı larvalar çoğunlukla hastalık belirtisi ortaya çıkmadan arılar tarafından kovandan uzaklaştırıldığından hastalık fark edilemeyebilir. Arı larvaları etkeni beslenme sırasında arıların taşıdıkları besinlerle sindirim sistemine alırlar. Larvanın sindirim sistemine yerleşen etken bağırsakta gelişir ve yavru pupa dönemine girdikten sonra dışkı ile petek gözüne atılır. İşçi arılar petek gözlerindeki bu artıkları temizlerken hastalığı sağlıklı larvalara bulaştırırlar. Taşıyıcı durumda olan ergin arılar bu hastalıktan etkilenmezler. Hastalık 3-4 günlük larvaları daha çok etkiler (Russenova ve Parvanov, 2005; Forsgren, 2010).
Hastalığın bulaşma yolları AYÇ ile aynıdır. Hastalığın klinik bulguları;

Larvalar genellikle 3-4 günlük iken hastalığa yakalanır. Petekteki yavrulu alanlar düzenli değildir. Yamalı yavru modeli görülür (Alacalı görünüm). Petekte aynı yerde yaşlı larva, genç larva, yumurta ve boş hücreler bir aradadır. Yavru ölümlerinin \%90'ı açık yavru gözlerindedir. Ancak hastalık şiddetli ve ilerlediyse kapalı yavru gözlerinde de ölümler görülür. Kaplı yavru gözlerinde ölüm olursa gözlerin sır tabakası çöker ve rengi açılır. Sekonder etkenler nedeniyle kapalı yavru gözleri delinir. Ölen larvalar parlak inci beyazı renklerini kaybeder ve vücutları şeffaf bir hale dönüşür. Barsakları ve trakeaları dışarıdan görülebilecek şekildedir. Larvalar göz içinde $C$ durumunda kıvrık bir şekilde ölür, sonra dibe çöker (Figür 5). Ölü larvanın rengi sarımsı renkten kahverengiye ve sonra da siyaha dönüşür. Çürüyen larvada yapışkanlık ve uzama çok az veya hiç yoktur. Hatta bazen larva tamamen kuru bir hal alır. Ancak sekonder etkenler devreye girdiğinde çok az uzama ve yapışkanlık oluşur, kibrit çöpü ile ölü larvaya dokunulduğunda $2-4 \mathrm{~cm}$. uzama görülebilir. Koku normalde yoktur, ancak sekonder etkenler $P$. alvei ve $E$. faecalis enfeksiyona katıldığında ağır bir bozuk et kokusu hissedilir. Hastalık şiddetlenerek ilerlediğinde klinik bulgular AYÇ ile karışabilir (Alippi, 1999; Tutkun ve Boşgelmez, 2003; Anonymus, 2007; Forsgren, 2010; Hutton, 2013).

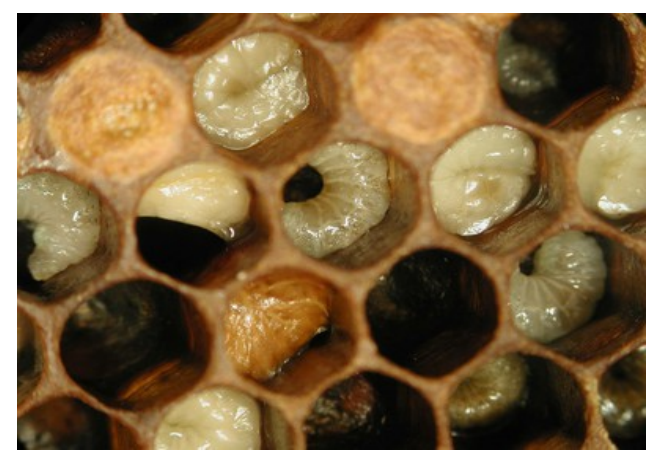

Figür 5. www.coloss.org

AvYÇ zamanında teşhis edilip mücadele edilmezse hastalık ilerler ve kovan yakmak gerekebilir. Hastalık çıkan kovanlarda ana arının yenilenmesi, hastalıklı yavrulu peteklerin imha edilmesi, stresten kaçınılması, sağlıklı ve güçlü kovanlardan yavrulu peteklerin verilmesi ve kovanın 1:1 oranında şurup ile beslenmesi gibi yöntemler hastalıkla mücadelede oldukça iyi sonuçlar vermektedir (Genç 


\section{DERLEME MAKALESI / REVIEW ARTICLE}

ve Dodoloğlu, 2002; Tutkun ve Boşgelmez, 2003; Russenova ve Parvanov, 2005; Forsgren, 2010).

Gereksiz ve bilinçsiz antibiyotik kullanımı, hastalığın baskılanmasını ve erişkin arıların hastalıklı larvaları kovandan uzaklaştırmasını sağlar. Ancak larvalar hastalığı atlatsalar da bulundukları yavru gözlerinde etken yaşamını sürdürür ve yeni yavrular döneminde hastalık yeniden ortaya çıkar. Koruma, kontrol, teşhis ve mücadele yöntemleri AYÇ ile aynıdır.

AYÇ ve AvYÇ arasındaki klinik belirtilerin farklılıklarını kısaca Tablo 1.'de özetlenmiştir.

\section{SEPTISEMI}

Septisemi, ergin bal arılarının, Pseudomonas apiseptica adı verilen bakteriler tarafından oluşturulan bir hastalığıdır. Gram negatif ve sporsuz bir bakteridir.Etken doğada nemli toprakta, bitkilerde, durgun su ve bataklıklarda bulunur. Solunum yoluyla bulaşır. Havasız ve yüksek oranda nem bulunan kovanlarda rastlanır. Stres faktörleri hastalık riskini arttırır.Hastalığa yakalanan arıların hemen hepsi kısa sürede ölür. Ölüm bulaşmadan 20-36 saat sonra en yüksek düzeye ulaşır. Arıların kaslarında hızlı refleks kaybı oluşur, rengi siyahlaşır, uçma yeteneği kaybolur. Arı zayıf ve halsiz düşer, ağır, ağır yürür, kolayca yakalanır. Düşkün bir halde bacak ve ağız parçalarını oynatır. Kasları dejenere olduğundan hastalıklı arıların eklem yerlerinden tutmak mümkün olmayıp bacaklar, baş, göğüs, karın ve kanatlar dokunur dokunmaz kolaylıkla kopar. Hasta arının kan rengi, açık kahverengiden tebeşir beyazına dönüşür. Bulaşık kovanlardan hoşa gitmeyen ekşi, çürük koku hissedilir.Hastalığınherhangi bir tedavi yöntemi geliştirilmemiştir. Arılığın kuru, temiz, güneş alan yerlerde kurulması, gerekli ve uygun beslemelerin yapılması ve arılarda stres oluşturan faktörlerin ortadan kaldırılmasıyla hastalıktan korunulmuş olunur.Ayrıcaçevrede pis ve durgun suların bulunmamasına dikkat etmek gibi önlemler alınabilir (Alippi, 1999; Tutkun ve Bosgelmez, 2003; Uygur ve Girişgin, 2008).

\section{Tablo 1. AYÇ ve AvYÇ arasındaki klinik belirtilerin farklılıkları}

\begin{tabular}{|c|c|c|}
\hline Belirtiler & AYC & AvYÇ \\
\hline $\begin{array}{l}\text { Yavrulu peteğin } \\
\text { görünüm }\end{array}$ & $\begin{array}{l}\text { *Petekte düzensiz yavru gözleri nedeniyle bul- } \\
\text { maca, alacalı görünüm, } \\
\text { *Ölümler kapalı yavru gözlerinde, } \\
\text { *Hücre kapakları çökük ve toplu iğne başı } \\
\text { şeklinde delinmiş, } \\
\text { *Hastalıklı petek gözleri koyu renkte }\end{array}$ & $\begin{array}{l}\text { *Petekte düzensiz yavru gözleri nedeniyle bul- } \\
\text { maca, alacalı görünüm, } \\
\text { *Ölümler açık yavru gözlerinde, hastalık şid- } \\
\text { detlenirse açık gözlerde de ölüm görülebilir. } \\
\text { *Hücre kapakları çökük ve toplu iğne başı } \\
\text { şeklinde delinmiş, } \\
\text { *Hastalıklı petek gözleri değişken renklerde }\end{array}$ \\
\hline $\begin{array}{l}\text { Ölü larvanın yaşı ve } \\
\text { görünümü }\end{array}$ & $\begin{array}{l}{ }^{*} \text { Genellikle yaşlı, kapalı gözlerdeki larva veya } \\
\text { genç pupa, } \\
\text { *Hücre içinde yukarı doğru dik pozisyonda ölüm } \\
\text { (Öküz dili görünümü) }\end{array}$ & $\begin{array}{l}\text { *Genellikle açık gözlerdeki 3-4 günlük genç larva } \\
\text { nadiren kapalı gözlerdeki yaşlı larva, } \\
\text { *Hücre içinde kıvrık pozisyonda (C şeklinde) } \\
\text { ölüm. }\end{array}$ \\
\hline Ölü larvanın rengi & $\begin{array}{l}\text { Öncelikle mat beyaz, daha sonra sırasıyla açık } \\
\text { kahverengi, çikolata rengi, koyu kahverengi ve } \\
\text { siyah }\end{array}$ & $\begin{array}{l}\text { Öncelikle mat beyaz, daha sonra sırasıyla } \\
\text { sarımsı beyaz, koyu kahverengi ve siyah }\end{array}$ \\
\hline Ölü larvar & $\begin{array}{l}\text { *Yumuşak, yapışkan, bir çöp ile çekildiğinde 2.5- } \\
10 \mathrm{~cm} \text {. uzama, } \\
\text { *Hücreden atılması zor }\end{array}$ & $\begin{array}{l}\text { *Sulu, hamurumsu, nadiren yapışkan, bir çöp ile } \\
\text { çekildiğinde } 2-4 \mathrm{~cm} \text {. uzama, granüler, } \\
\text { *Hücreden atılması kolay }\end{array}$ \\
\hline Ölü larvanın kokusu & Hafif zamk kokusu & $\begin{array}{l}\text { Koku yoktur ya da ilerleyen olaylarda ekşi veya } \\
\text { bozuk et kokusu }\end{array}$ \\
\hline
\end{tabular}

kültürel ve moleküler metodlar ile etkenin tanımlanması ile yapılabilir.

\section{TOZLU PUL HASTALIĞI (POWDERY SCALE DISEASES)}

Hastalığın etkeni Paenibacillus larvae subsp.pulvifaciens'dir. Oldukça nadir görülür. Arıcının hastalığı tanımlaması çok zordur. Larva kuru, tozlu, açık kahverengiden sarıya değişen pul gibi görünümlüdür. Larvaya dokunulduğunda toz gibi dağılır (Alippi, 1999; Shimanuki ve Knox, 2000).
Hastalığın etkeni Bacillus coagulans'tır. Etken 1-4 günlük larvaları etkiler. Hastalanan larva petek gözünün tabanında yarım ay şeklinde kıvrılmış olarak ölür. Bulguları AvYÇ benzer. Kraliçe arı kaynaklı bir hastalıktır. Hastalıklı larva bulunan petekler sağlıklı kolonilere verildiğinde hastalık oluşmazken, hastalıklı kovanın kraliçesi sağlıklı kovana verilirse hastalık meydana gelir. Ana arının değiştirilmesi en iyi mücadele yönetmidir (Vandenberg ve Shimanuki, 1990; Alippi, 1999). 


\section{DERLEME MAKALESI / REVIEW ARTICLE}

\section{SPIROPLASMOSIS}

Erişkin arıları etkiler. Hastalığın etkeni Spiroplasma melliferum'dur. Erkek ve işçi arılarda şiddetli infeksiyonlara sebep olabilir. Hastalığa ilkbahar sonu ve yaz başında daha sık rastlanır. Arılar halsizdir ve genellikle 1 hafta içinde ölürler. Spiroplasma apis tarafından oluşturulan bir diğer hastalık da Mayıs hastalığıdır. Arıların karınları şişmiştir. Kovan çevresinde ve içinde saldırgan hareketlerde bulunurlar. Ölü ya da can çekişen arılar mevcuttur. Etkilenen koloniler Temmuz ayında kendiliğinden düzelirler (Alippi, 1999).

\section{ADI YAVRU ÇÜRÜKLÜĞÜ}

AYÇ, AvYÇ ve Septisemi hastalığına Türkiye'de rastlanır. Ancak bu hastalıkların dışında oldukça yaygın olan ve arıcılar tarafından özellikle AYÇ ve AvYÇ ile karıştırılan Adi yavru çürüklüğü vardır. Bu hastalık AYÇ ve AvYÇ ile aynı klinik bulguları göstermekte ve arıcılar arasında korku oluşturmaktadır. $\mathrm{Bu}$ hastalığın etkenleri çok çeşitlidir. Etkenler; insan, hayvan ve çevre orjinlidir. Bacillus spp., Corynebacterium spp., Stapylococcus spp. ve Streptococcus spp. en sık rastlanılan etkenlerdendir (Hutton, 2013).

Bir kolonide hastalığın çıkmasında; Arının Genetik Yapısı,

Koloni gücü,

Kolonideki Yavru - Yetişkin arı oranı,

Polen ve nektar toplama, koloniler arası ve yıllar arası farklılıklar önem taşımaktadır.

Uludağ Üniversitesi Arıcılık Geliştirme, Uygulama ve Araştırma Merkezi ile yaklaşık 7 yıl boyunca Bursa, Balıkesir, Çanakkale, Bilecik ve Yalova'da yapılan ortak çalışmalarımızda AYÇ şüpheli bulgular tespit edilen kovanlardan örnekler alınmış ve dünya standartlarındaki kültürel ve moleküler teknikler ile incelenmiş ve örneklerin hiçbirinde AYÇ etkenine rastlanmamıştır. Aynı zamanda Türkiye'nin birçok şehrinden gelen numuneler incelenmiş ve AYÇ etkenine rastlanmamıştır. Hastalıklı kovanlardan elde edilen etkenlerin hepsi hayvan, çevre ve insan orjinlidir. Çok basit birkaç hijyenik önlemin alınması ile yavru çürüklüğü hastalıkları engellenebilmektedir. Böylece arıcının gereksiz korkuları ve bilinçsiz antibiyotik kullanımları engellenerek hem arıcı ekonomik olarak ciddi kayıplara uğramayacak hem de tüketici daha kaliteli ve sağlıklı ballar tüketebilecektir.

Sadece klinik bulgulara bakarak teşhise gitmek hata ve zaman kaybına sebep olur. Kesin teşhis için hastalık şüphesi olan kovanlardaki özellikle hastalık belirtilerini taşıyan $10 \times 15 \mathrm{~cm}$ 'lik bir parça alınarak en kısa sürede arı hastalıkları teşhis laboratuvarına gönderilmelidir.

Hastalık çıktığında doğru teşhis yapılana kadar hastalıklı kovan arılıktan uzaklaştııılmalı, kovan girişi daraltılmalı, diğer koloniler tarafından yağma edilmesi engellenmelidir. $\mathrm{Bu}$ arada eldivenler ve diğer arıcılık ekipmanları mutlaka dezenfekte edilmelidir. Hatta hastalıklı kovanın incelenmesi için ayrı bir el demiri ve eldiven kullanılmalıdır. Eğer el ile kontrol yapılıyorsa, arıcılar mutlaka ellerini bol sabunlu ılık su ile yıkamadan diğer kovanları kontrol etmemelidir.Hastalık arııkta çok yayıldıysa bu kovanlardan elde edilen ballar, yavrulu petekler, çerçeveler imha edilmeli, diğer arııklar arasında arı hareketleri ve alet-ekipman kullanımı, ana arı, yavrulu petek değişimi engellenmeli, uygun dezenfeksiyon yöntemleri uygulanarak arılık diğer arılıklardan izole edilmelidir.

Kovanların yavru çürüklüğü riski taşıyıp taşımadığını belirlemek ve önlem almak için birkaç basit değerlendirme yapılabilir (Tablo 2).

Türkiye, arıcılığa elverişli iklim koşullarına ve zengin bitki örtüsüne sahip olan, dünyanın sayılı ülkelerinden biridir. Ülkemizde arıcılığın gelişmesini sağlamak için arı zararlıları ve mücadele yöntemleri bilinmeli, arıcılığı destekleyen kuruluşlar kurulmalıdır.Türkiye ekonomisine önemli katkıda bulunabilecek bu sektöre gereken önemin verilmesi ve ekonomik zararların en az düzeye indirilmesi için hastalıkların tanınması ve etkili mücadele yöntemlerinin belirlenmesi gereklidir. Çok basit hijyenik önlemlerin alınması arıcılarımızın kovanlarını AYÇ ve AvYÇ gibi önemli bakteriyel hastalıklardan korunmasını sağlayacaktır. 


\section{DERLEME MAKALESI / REVIEW ARTICLE}

Tablo 2. Yavru çürüklüğü riskinin belirlenmesi ve alınabilecek önlemler

\begin{tabular}{|c|c|c|c|}
\hline \multirow[b]{2}{*}{ RİSK BELİRLENMESi̇ } & DÜŞÜK RİSK & $\begin{array}{l}\text { ORTA } \\
\text { RISK }\end{array}$ & $\begin{array}{l}\text { YÜKSEK DEREDE } \\
\text { RISK }\end{array}$ \\
\hline & $\begin{array}{l}\text { Yılda } 2 \text { kez yavru } \\
\text { çürüklüğü şüpheli klinik } \\
\text { bulgular gözlenmesi }\end{array}$ & $\begin{array}{l}\text { Yılda 2'den fazla yavru } \\
\text { çürüklüğü şüpheli klinik } \\
\text { bulgular gözlenmesi }\end{array}$ & $\begin{array}{l}\text { Her incelemede yavru } \\
\text { çürüklüğü şüpheli klinik } \\
\text { bulgular gözlenmesi }\end{array}$ \\
\hline \multirow[b]{3}{*}{$\begin{array}{l}\text { ALINABILECEK } \\
\text { ÖNLEMLER }\end{array}$} & $\begin{array}{l}\text { Periyodik olarak petek } \\
\text { değişimleri yapılması }\end{array}$ & $\begin{array}{l}\text { Düzenli ve sistematik } \\
\text { olarak petek değişimleri } \\
\text { yapılmalıdır }\end{array}$ & $\begin{array}{l}\text { Yapay oğul/İnfekte } \\
\text { kolonilerin imhası }\end{array}$ \\
\hline & Basit hijyenik önlemler & $\begin{array}{l}\text { Dikkatli hijyenik önlem- } \\
\text { ler }\end{array}$ & Sıkı hijyenik önlemler \\
\hline & $\begin{array}{l}\text { Yapay oğul/İnfekte } \\
\text { kolonilerin imhası }\end{array}$ & $\begin{array}{l}\text { *Yapay oğul/İnfekte } \\
\text { kolonilerin imhası } \\
\text { *Arılık düzeyinde karan- } \\
\text { tina }\end{array}$ & $\begin{array}{l}\text { *Temas halindeki } \\
\text { kolonilerden de yapay } \\
\text { oğul elde edilmesi } \\
\text { *Koloni düzeyinde } \\
\text { karantina } \\
{ }^{*} \text { Arılığın izolasyonu }\end{array}$ \\
\hline
\end{tabular}

Ayrıca sadece klinik bulgulara bakılarak yapılan değerlendirme tamamen zaman kaybıdır ve yanlıştır. Tüm dünyada da kabul edilen yol, etkenin kültürel ve moleküler yöntemler ile teşhis edilmesidir. Klinik bulgular sadece fikir verebilir ve basit önlemler alınmasına yardımcı olur.

Doğru bakım, doğru hastalık teşhisi ve doğru mücadele yöntemleri ekonomik kayıpları engelleyecektir.

\section{KAYNAKLAR}

Alippi, A.M. 1999. Bacterial diseases CIHEAMOptions Mediterraneennes.

Alippi, A.M., Ringuelet J. A., Cerimele E. L., Re M. S., Henning C. P. 1996. Antimicrobial Activity of Some Essential Oils AgainstPaenibacillus larvae, the Causal Agent of American Foulbrood Disease. Journal of Herbs, Spices \& Medicinal Plants, 4 (2): 9-16.

Alippi, A.M., Aguilar O.M. 1998. Characterization of Isolates of Paenibacillus larvae subsp. larvae fromDiverse Geographical Origin by the Polymerase Chain Reaction and BOX Primers. Journal ofInvertebrate Pathology, 72: 21-27.

Anonymous. 2007. Foul Brood Disease of Honey Bees: Recognition and Control. Defra, London

Arbia, A., Babbay B. 2011. Management strategies of Honey bee Diseases. Journal of Entomology, 8 (1): 1-15.

Bailey, L., Ball B.V. 1991. Honey Bee Pathology, Academic Press, London, Second Edition.

Bogdanov, S. 2009. Beeswax: Production, Properties Composition and Control. Bee Produt Science, Beeswax Book, Chapter 2.

De Graaf, D.C., Alippi A.M., Brown M., Evans J.D., Feldlaufer M., Gregorc A., Hornitzky M., Pernal S.F.,Schuch D.M.T, Titera D., Tomkies V., Ritter W. 2006. Diagnosis of American foulbrood in honey bees: a synthesis and proposed ana-
Iytical protocols. Letters in Applied Microbiology, 43: 583-590.

De Graaf D.C., Alippi A.M., Antunez, K., Aronstein, K. A., Budge G., De Koker, D; De Smet L.,

Dingman D. W., Evans J. D., Foster L.J., Fünfhaus A., Garcia-Gonzalez E., Gregorc A., Human

H.,Murray K. D., Nguyen B. K., Poppinga L, Spivak, M., Vanengelsdorp D., Wilkins S., Genersch E.2013.Standard methods for American foulbrood research. In V Dietemann; J D Ellis; $P$ Neumann (Eds) The COLOSS BEEBOOK, Volume II: standard methods for Apis mellifera pest and pathogen research. Journal of Apicultural Research,52(1): 1-27.

Djordjevic, S. P., Forbes, W.A. Wendy, A., Smith L.A., Hornitzky, M.A. 2000. Genetic and Biochemical Diversity among Isolates of Paenibacillus alvei Cultured from Australian Honeybee (Apis mellifera) Colonies. Applied and Environmental Microbiology, 66 (3): 1098-1106.

Dobbelaere, W., De Graaf, D.C., Reybroeck, W., Desmedt, E., Peeters, J.E., Jacobs F.J. 2001. Disinfection of wooden structures contaminated with Paenibacillus larvae subsp. larvae spores. Journal of Applied Microbiology, 91 (2): 212-216.

Doğaroğlu, M. 2000. Modern Arıcılık Teknikleri, Tekirdağ. 


\section{DERLEME MAKALESI / REVIEW ARTICLE}

Engels, W., Nicholson, G. J., Hertle, R., and Winkelmann, G. 2004. Tyramine functions as a toxin inhoney bee larvae during Varroatransmitted infection by Melissococcus pluton. Fems Microbiology Letters, 234 (1):149-154.

Forsgren E. 2010. European foulbrood in honey bees.Journal of Invertebrate Pathology, 103: 5-9.

Forsgren E., Budge G. E., Charriere J. D., Hornitzky M. A. Z. 2013. Standard methods for European foulbrood research. In V Dietemann; J D Ellis, P Neumann (Eds) The COLOSS BEEBOOK: Volume II: Standard methods for Apis mellifera pest and pathogen research. Journal of Apicultural Research, 52(1):1-14.

Genç, F., Dodoloğlu, A. 2002. Arıcılığın Temel Esasları. Atatürk Üniv. Ziraat Fak. Ders Yayınları. No: 166. Erzurum.

Gende L. B., Flori I., Fritz R., Eguaras M. J. 2008. Antimicrobial activity of cinnamon (Cinnamomumzeylanicum) essential oil and its main components against Paenibacillus larvae from Argentine. Bulletin of Insectology, 61(1): 1-4.

Gende, L. B., Maggi, M. D., Fritz R., Eguaras M. J., Bailac P. N., Ponzi M. I. 2009. Antimicrobial Activityof Pimpinella anisum and Foeniculum vulgare Essential Oils Against Paenibacillus larvae. Journal of Essential Oil Research, 93(21): 91-93.

Genersch, E. 2010. American Foulbrood in honeybees and its causative agent, Paenibacillus larvae Journal of Invertebrate Pathology, 103:10-19.

Guzmana, Z. M., Cervanciab, C. R., Dimasuaya, K. G. B., Tolentinoa M. M., Abreraa G. B., Cobara, M. L. C., Fajardo A. C., Sabinob N. G., Manila-Fajardob A. C., Chitho P. F. 2011. Radiation inactivation of Paenibacillus larvae and sterilization of American Foul Brood (AFB) infected hives using Co-60 gamma rays. Applied Radiation and Isotopes, Volume 69 (10):1374-1379.

Hansen, H., Brodsgaard C.J. 1997. The spread and control of American foulbrood. Bees for Development Journal, 76: 12-13.

Human, H., Pirk, C.W.W., Crewe, R.M., Dietemann, V. 2011. The honeybee disease American foulbrood-An African perspective. African Entomology, 19(3): 551-557.
Hutton, S. 2013. Foulbrood diseases of honeybees and other common brood disorders. The Food andEnvironment Research Agent (online) Available at: https://secure.fera.defra.gov.uk/.../downloadDo

İnal, Ş.,Güçlü, F. 1998. Arı Yetiştiriciliği ve Hastalıkları, Konya.

Kaftanoğlu, O., Yeninar, H., Kumova, U., Ozkok, D.1995. Epidemiology and control of honeybee (Apis mellifera L.), diseases in Turkey. TUBITAK Project No VHAG-925, TUBITAK Publication No: 92-0054, Final Report. 93 pp. Ankara.

Kamburov, G., Parvanov, P. 1987.European foulbrood. Apiculture, 4:26-28.

Karacaoğlu, M. 2012. Türkiye arıcılığının yapısal analizi. Standart Ekonomik ve Teknik Dergisi, 51(601):26-33.

Konak, F. 2012. Türkiye'de arıcılığın gelişimi ve verimlilik çalışmaları. Standart ekonomik ve teknik dergisi, 51(601): 34-39.

Matheson, A.; Reid, M: 1992. Strategies for the prevention and control of American foulbrood.American Bee Journal, 132 (6-7-8): 399-402;471-475;534-537,547.

Morse R.A., Nowogrodzki R. 1990. Honey Bee Pests, Predators and Diseases, Cornell University Press, Ithaca and London.

Okayama, A.,Sákogawa, T., Nakajima, C.,Hayama, T. 1997. Sporicidal activities of disinfectants on Paenibacillus larvae. The Journal of Veterinary Medical Science / the Japanese Society of Veterinary Science, 59(10):953-954.

Parvanov P., Russenova N., Dimov D. 2006. Control of American foulbrood disease without anibiotic use. Uludag Bee Journal, 3(1):97-103.

Ritter, W. 1996. Diagnostik und Bekämpfung von Bienenkrankheiten.Gustav Fischer Verlag, Jena.

Russenova, N.,Parvanov P. 2005. European Foulbrood Disease-Aetiology, Diagnostics and Control. Trakia Journal of Sciences, 3(2):1016.

Schäfer, M.O., Ritter,W., Pettis, J., Neumann, P. 2010. Small hive beetles, Aethina tumida, are vectors of Paenibacillus larvae. Apidologie,41: 14-20.

Shimanuki H., Knox D.A. 2000. Diagnosis of Honey Bee Diseases, Agriculture Handbook, Department of Agriculture. 


\section{DERLEME MAKALESI / REVIEW ARTICLE}

Tutkun, E. 2000. Teknik Arıcılık El Kitabı, Türkiye Kalkınma Vakfı, Yayın No: 6, Ankara.

Tutkun, E., Boşgelmez, A. 2003. Bal Arısı Zararlıları ve Hastalıkları Teşhis ve Tedavi Yöntemleri, Bizim Büro Basımevi, Ankara.

Uygur, Ş.Ö., Girişgin A.O. 2008.Bal arısı hastalık ve zararlıları.Uludag Bee Journal, 8(4):130-142.

Vandenberg, J.D.; Shimanuki H. 1990. Isolation and characterization of Bacillus coagulans associated with half-moon disorder of honey bees. Apidologie 1990, 21: 233-241.

\section{EXTENDED ABSTRACT}

Goal: The goal of this review to inform bee scientists and beekeepers about foulbrood diseases, prevention and control.

Introduction: Turkey has a great potential for beekeeping. Geographical structure, rich flora, nectar sources, ecology, colony, and genetic variation in the populations of bees for honey production terms are very affordable for beekeping in Turkey. However, despite all these advantages, our honey production and exports are not good. Lack of technical knowledge, care and nutritional deficiency, queen bee production failure, wintering ignorance, disease and pests are not known, and consequently timely diagnosis and treatment can not be made, the necessary control and prevention methods are not applied to the situations. Diseases can be divided into two groups. Adult bees diseases and foulbrood diseases. American and European foulbrood factors leads to significant losses in beekeeping, beekeeping economy and great harm. Beekeepers used appliances and equipment, diseased hives, contaminated honey with nutrition, robbing, old hive inadequate sterilization again with the use of contaminated bee honey and pollen by the use as food becomes. Among the purity of bee products, adult bees and queen bees, hives and beekeeping equipment used to control the movements of the foulbrood is quite important in the transmission of diseases.

Conclusion: Prevention of these diseases is more important than treatment. In particular, to pay attention to just a few simple rules of hygiene in the prevention of these diseases will be much more useful. In this article frequently encountered in beekeeping foulbrood diseases, reliable diagnosis, prevention and control methods is given about. 